\title{
內地市町村別都市指數の分布と地域區分（2）
}

\author{
土井喜久一
}

\section{IV 經濟形態及經濟階梯との關係}

以上の考察の結論として，低い都市指數は（大體20以下）は農業及び水座 業より成る原始產業形態の町村に該當し，中位の指數（20一約70）は工業を 主とする加工及び交換經濟形態を表はし，高位の指數（70以上時には77以下 も）は都市經濟なる，交換及び工業生產の著しく集中された形態に對應して 居る。そして前二者にあつては特に，其の指數の大小は其の形態內の經濟階 梯の高低を反映してるる。

\section{V 都市指數に依る地域區分と其の意義}

我々は既に第 3 章に於て都市指數の分布が，核心地域と呼んだ高指數部か ら，阿地全體に互つて，周圍に向つて低下してねるのを知つた。又前章に於 て其の個々の指數の大小が有する意味を知り，從つて其の指數區域に屬する 地域の性質を，それから演繹的に知る事が出來る。最も普遍的なる農業に於 ては此の核心地域の農業が全體として集約化されて居り, 商品生產化が進ん でなる事，他方緣邊地域に於ては，農業が未だ粗放の狀態にあり自給自足の 傾向が强い事は絊多の文獻に依つて知られ，又農家一戶當耕地面積 (第7圖)

29) 例へば東北地方については人口問題調查會編東北地方の人口に關する研究，社會 政策時報 No. 174 東北問題研究(昭 10), 又近畿地方に就いては, 松井武敏：紀

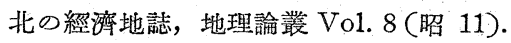

小松幸雄：近郊農村の性格, 大阪商大經濟學雜誌 Vo1. 1. pp. 797-814. 
或は区當收嚄高（第8圖）からも察せられる。又工業も此の核心地域に近代的 工場工業が集中し，緗邊地域に於て之を缺く。

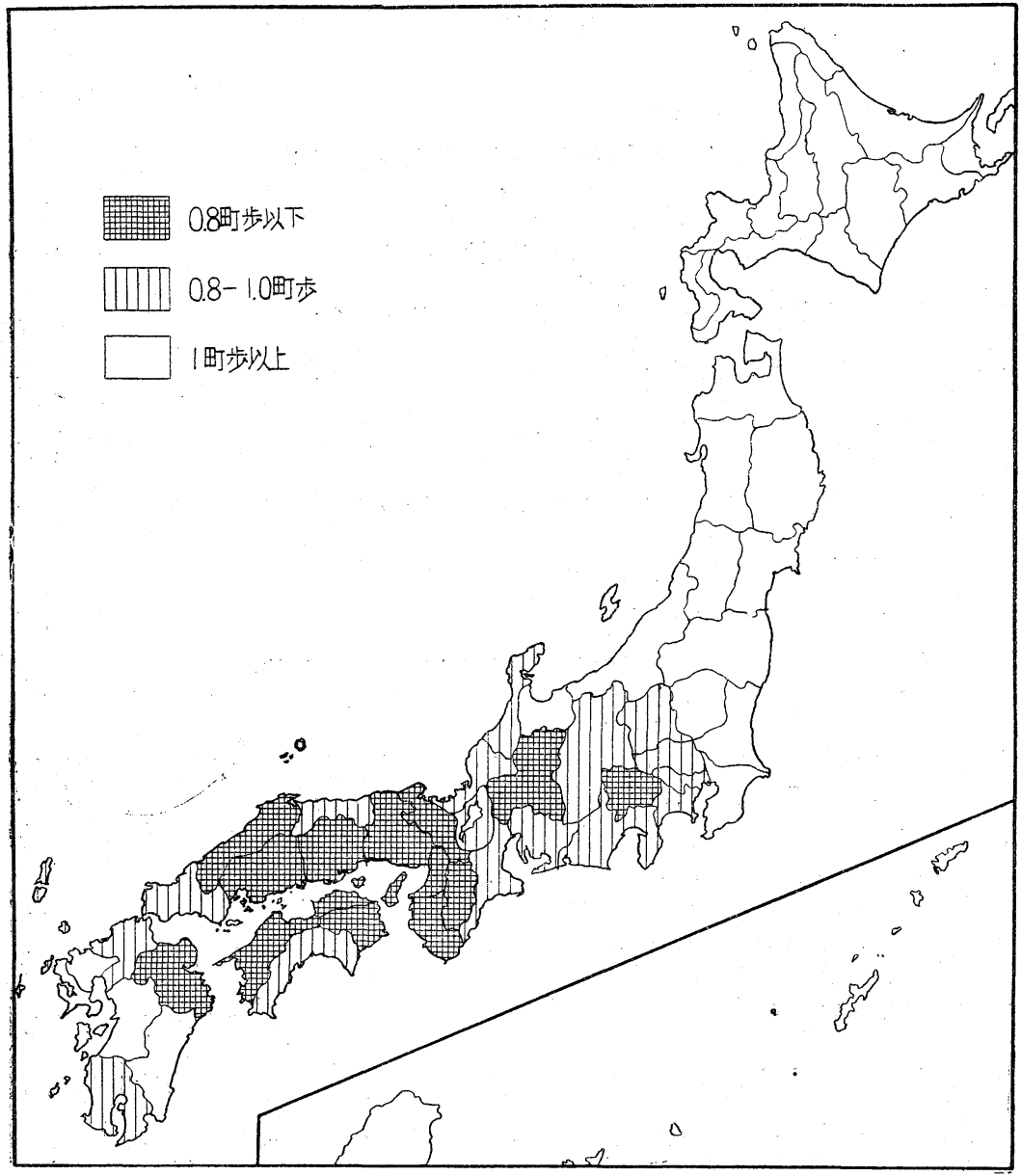

第 7 圖 縣 別, 農 家一戶當耕 地 面 積

かかる地域的差異は更に種々なる現象に現はれ，例へば商業形態に於ては 緣邊地域に於ては今日尚小賣の市が日常經濟生活上主要なる役割を果してね 
るが，核心地域に於ては商業の重要性の增加と共に定常的なる商店の發達が 進んで，かかる小賣市場は早く消滅したか，或は緣日，祭禮等の際極めて特

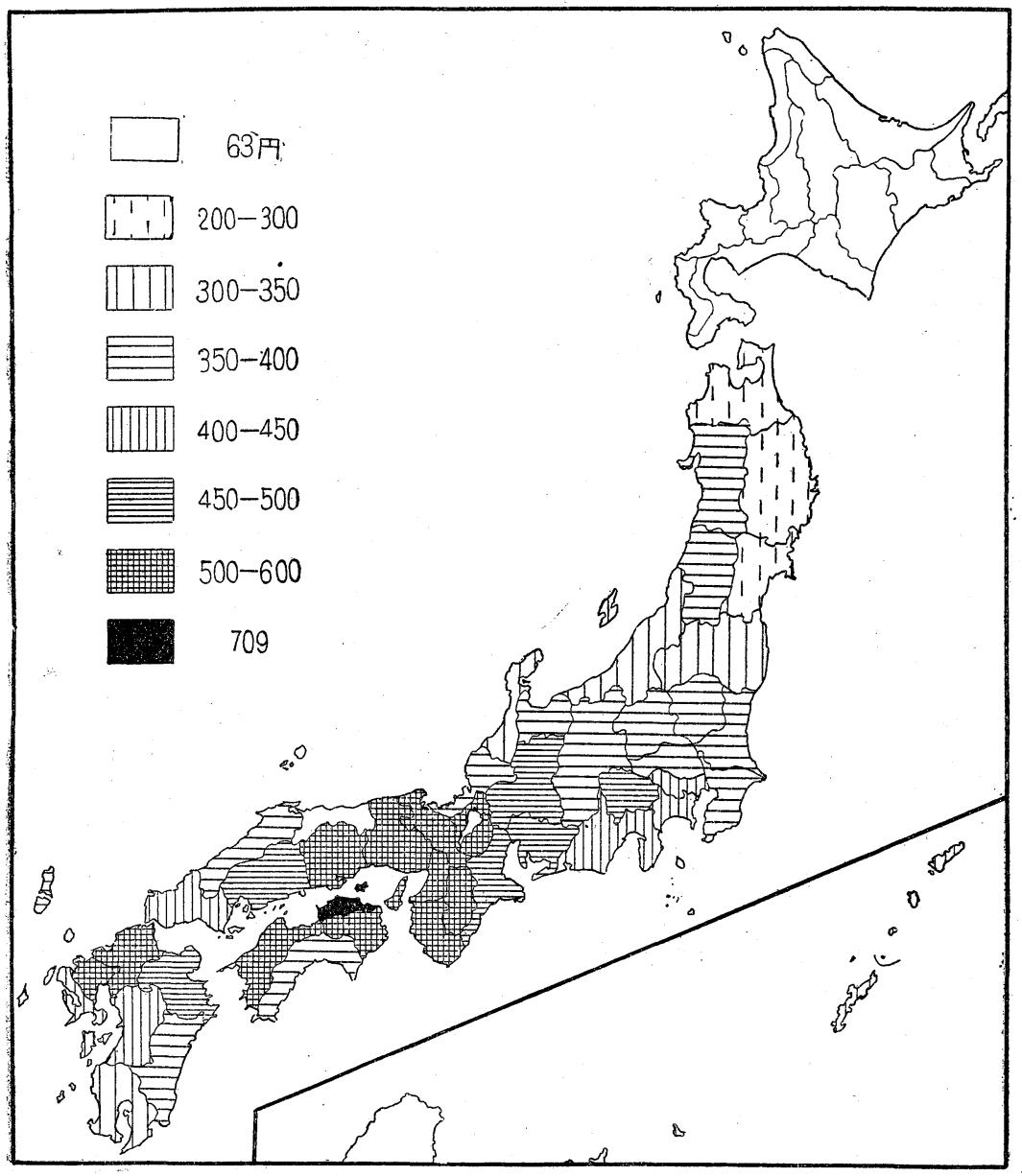

第 8 圖 縣 別,耕地一町步 當收入

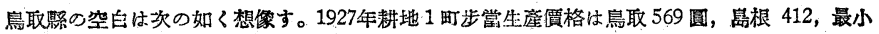
の北海道 184, 最大の香川 881 となれる故, 收入に於ても鳥取は鼻根と周しか之より稍:良き

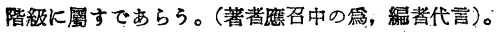


殊的商品（日常經濟的需要の乏しき品）を商ぶのに變質してるる。

かかる現象の綜合に依つて此等の地域の經濟生活及びそれれに制約せられた

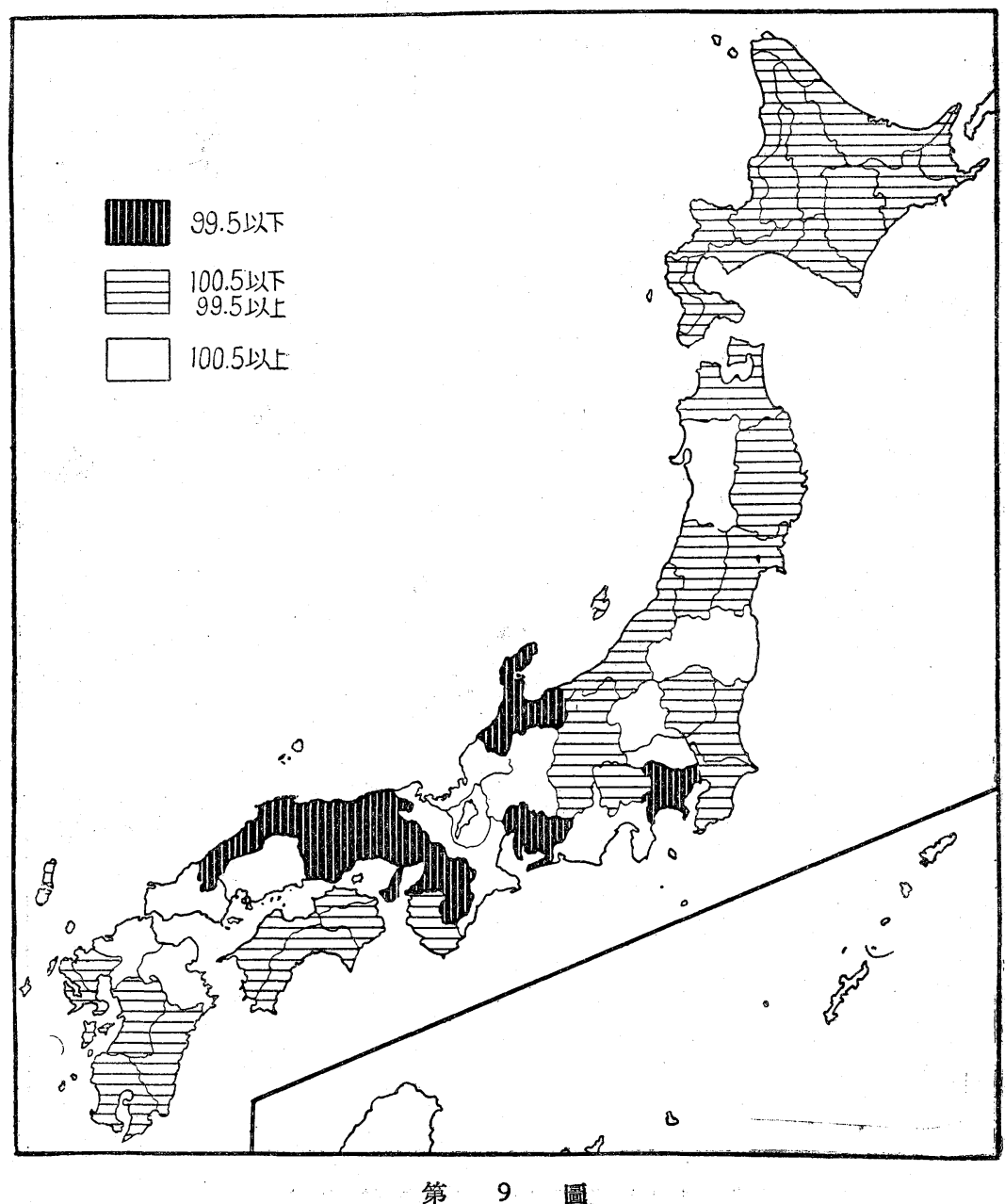

第 9 圖

3) 田中館秀三，高橋幹雄：横手盆地に於ける㠳場の研究，地評 Vo1. 13. pF・ 141 $-166,208-226$.

同 : 米代川流域に於ける市場の犐究，地評 Vol. 13 pp. 1C45-1068. 
る社會生活の內容を詳しく系統立てる事が必要であると共に，更に進んで， かかる地域的差異を生ぜしめたる原因に關して考察せねばならない。

近畿地方を中心として，指數が周圍に向つて低下する狀態は，丁度奈良朝 以後の我國文化が此の地方から僻遠の地に向つて波及した狀態に類似して居 る。單に文化のみならず，其の文化を定着せしむべき開拓の事業も，漸次東 北及西南日本に向つて進んだ事は明かな事實である。全體としての分布が一 致するのみならず，或は途中を飛び越え，自然的障害に依つて妨げられたり した文化の傳播と，指數の高低も一致するが如くである。例へば古くから開 けた筑紫の地北九州支び山口縣が，現在の鑛業地以外に於ても，中國地方， 四國地方より指數高く，又地理的環境の豐饒性よりも，政治的考慮に依つて， 德川氏以來日本の政治，文化の中心となつた汇月の地，東京の地が中部地方 東部より滛に指數高き二次的中心をなすが如きはそれである。而して，かか る文化の傳播，開拓の進行と指數の高低との熬がりは何に依つて起るのであ らうか。それは人口の相對的飽和に依つてである。茲に相對的と言ふのは人 口の飽和が，その土地自身に於ける絕體的限度に依つて規定されるものでな く，その土地の有する可能性と，それて㗢く文化營力との均合ひに依つて定 まるからである。文化營力の變化，生產力の增加は，一旦飽和した土地にも 更に人口を增加せしめるのである。德川時代中停滯してねた日本の人口が明 治以後急激に增加せる如きはその最も見易き例である。

31) 農業に於ても, 工業に於ても, 交化營力は, 長期に互つて可成同栐な性質のもの であつても，それは短期間の小波瀾を伴つてるる，師ち景氣現象である。景氣の 惡化例へば農業恐慌はすべての地方に互つて, 發展を一時停止せしめる。然し景 氣の上昇に伴つて發展が始まれば地域的條件の差異の影響が現はれる。故に地域 的條件は或場合には單に潛在的なるのに過ぎないが，地理學の追求するものは， 圭として之であり，現實の運動に於ては探算の良否なる經濟的現象が前面に現は れ來る。 
現在の日本の農業人口の飽和の程度は, 內地に於ても可成の地方的差異が

ある。大正 9 年一昭和 5 年の國勢調査に現れた農業人口の變化は第 9 目の如 く，明かに緣邊地域にはまだ農業人口吸收の餘地があり，飽和に達してねな い事が制る。又略同じ期間に耕地の增減も之と並行して，核心部に減少し緣 邊部に增加した。郎ち緣邊部に於ては耕地擴張の餘地が未だ存し，增加した る人口は主として農業の面積的撗大に依つて吸收されるが，核心部に於ては 最早撗張は不可能で農業技術の改良に依る人口收容力の增大か，商工業に向 つて人口が移動して行かねばならぬ。然してスかかる變化は必然的に資本の 集積及び勞働者階級の發生を促して近代工業成立の地盤を形成した。一旦中 央に工業が生れば，緗邊地方はとの後背地として受動的な立場に立ち，從來 の手工業は壓迫侵略を受け商業のみが或程度の發達を許されるが，それすら 子中央の商業の發展の程度には及ばぬ。中央の近代商工業の發澾はかくして, 農業發達の地盤の上に立ちつつ，更に著しい都市的人口の增加，夫は䚁局に 於て牛ば以上が國內緣邊部及び中央自身に依つて養はれ一部は貿易に依つて 海外飞低存するものである。要するに經濟史的發達の位相の差は，地理的同 時關係に依つて，國內の地域的分業に轉化し，それに依つて，個別的發達の 場合に成立すべき商工業分布の差以上の, 構造的差異を生ぜしめたのである。

\section{VI 都市指數分布の構造差異}

都市指數は前逝の如き全國的分布傾向を示す他，各地方地方に於て都市と 農村なる機能的關係に應じて高低あるは言ふ迄るない。都市と農村が相集り 地方の構造(大久保氏の Pattern)を成すが故に之を構造的差異と呼び度い。

32) 工業成立の基盤に就いては前述 R. Blanchard の所說參照。

33）此の構造, 地域的分業は, もとより歷史的に形成され, 從つて社會, 經濟的事情 の變化に依つて, 變形, 變質を受けるものである。大體に於てかかる地方中心都 
行政區劃的關係から，都市指數には地理的意味の，單一なる，都市，農村 それ自身の都市指數が必ずしも表現されてねるとは限らぬ事，第茿章の如く であり，先づ此の點が憼察されねばならね。

察際の都市指數分布圖を觀察すると平野の地方に於ては一般に，高き指數 を有する中心都市の周圍に，指數低き數ら村が存在する。又各中心都市が存 在する代りに一列を成して相互に接してねる場合もある。之は街道に沿つて るるもので, 東海道, 中國地方の海岸, 富山, 新潟縣, 東北地方の西海岸,

房總牛島海岸等に著しい。此は一般の平野の町村の面積が中心都市の商圈面 積より遙に小さく，後者に數個の村が含まれる故である。從つて此の場合中 心都市の指數は (2 B ) Type の地域の指數（第章）であつても商圈內の 村の指數は (1) type であつて意味がある。かかる構造の場合を理論的に考 へるならば，村にも完全に商店が存しない事は稀であるから，その商店の数 は都市の商業的勢力との均衝に於て決り，(種類的分化はあるが,都市の勢力 が弱い程分化の度が大となる）都市の勢力の減ずる，遠い村程村內に存する 商店が多かるべきである。(此の商店が, 特定の部落に集つて都市の芽生を示 すか, 各部落に散在するかは第二の問題である。) 多くの都市が存在する場合 にはその勢力の境界帶上に最も商店が多かる可く，要すると都市指數は中心

市の分布狀態は德川時代の末には現在と同じ狀態であつたと考へられる。その後 の產業の發展，交通の變化はかかる都市の性質機能に影響を及ぼし，之に依つて 新生した都市は（工業都市を除く）少いと考へられる。最近に於けるトラック運 送の普及は, 農村の商品經濟化々相俟つて農村自體の中に商品を發生せしめる傾 向を持つ。特に近畿地方の農村は內部に可成の商店を有して日用品の自給の程度 に達し, 都市との關係は, 高級品, 特殊品のみを依存する事となつて, 大いに薄 らいで來たかの裳である。此の點については更に將來の調査を期し度い。

34) 今村學郎, 磯崎優：地方都市の商圈に關する研究。

35) 其の場合村に存在する商店は，その質に於て，取扱商品が最も普遍的（特殊な品 質を限定せず，且つ需裂の多いもの，又小資本にて可能なるもの，例へば雜質， 一般的食料品 (米, 肥料, 㢦荣子) であり, 町に於けるものは高級品（曲服類） 及び特殊品 (時計, 藥品等) の店であり, 種類上の分化がある。 
都市を遠ざかる程增大すべきである。その例は然し，明瞭な同心圓狀分布を 示す程のbのは全く無く，要するに之は一つの傾向たるに止まり，

1）現實には他の諸要素の影響を受けて複雜化し或は打消され，

2） 又中心都市の分布が充分密で，かかる傾向に依る指數の差が大となり 得索いと考へられる。

次に都市と周邊部との第二の構造的關係は，通勤に依つて結び付けられ， 或は直接都市の膨脹に依る郊外形成の現象である。都市の勢力は，大體距離 （正確には交通の便否）に從つて減ずるから此の場合指數は都市から周圍に 向つて低下する。かかる郊外化の起つてねるのは主として，六大都市の周圍 （殊に東京，大阪の）に限られ，普通の市では全然かかる郊外を有しないか， 或は特定の方向にのみ郊外或は市の膨脹部を有してねる。又工業地域多同樣 の通勤現象に依つて周国の都市指數に影響を與へてるる。

山地の場合にあつては，構造は異つた指數上の表現を受ける事になる。山 地の町村は一般に，人口は本野の町村と略く同樣で面積は其の數倍に達する。 一方商圈を成す農村とが合して，行政上の一町村を作り，郎ち（2 B）又は (2 A) type の地域となる。斯くしてかかる山地では地方中心都市として表 現されない多數の中心があり，指數分布上かららは略み一樣の，純農村よりは 稍高い指數地域が生ずる。山地に存在する都市，例へば中國山地の津山，高 梁，西城等はかかる考よりすれば，一段高次の中心で，平野に於ては市に當

36) 竹內常行：新鼬，富山，石川三縣に於ける町村面積と地形並びに人口密度との關 係, 地理學評論 Vo1. 8. No. 7.(昭和 7 年)貲際の數字を擧げると〔山地〕廣島縣 比婆郡 22 ケ町村本均 $53 \mathrm{~km}^{2} 3100$ 人, 岡山䁻阿哲郡19ヶ町村 $43 \mathrm{~km}^{2} 2670$ 人，之 に對し，[本野]岡山縣都寉郡 16 ケ町村 $7.5 \mathrm{~km}^{2} 3860$ 人，香川縣大川郡 23 ケ町村 $13.3 \mathrm{~km}^{2} 3510$ 人 香川郡 22 ケ町村 $10.1 \mathrm{~km}^{2} 3540$ 人。

37) 此の理由のみからでは, 山地の指數の方が一船に本野の農村より高かるべきであ るが，事賔は左樣でないのは，山地の經濟的發達が迮れてるるからである。 
るものである。

山地に於けると同樣の關係が，北海道，宮崎及鹿兒島縣の面積大存る（此 の場合は人口も大）町村が普遍的である地方にも當てはなる。郎ち指僌の上 に表現される中心都市が少く全體としての指數が高い $(20-30)$ 。

以上要するに山地及び北海道等の地方では構造上の關係に依つて指數の值 が大となつてねるから，直接平野の指數と比較する事は出來ない。（郡平均を とれば此の差は大體消去出來るが中心都市の商圈は限界を越えて居る場合も 多いから嚴密とは云へない。)

山地と平地との都市指數の差 以上の構造的關係からは山地に於て指數が 高かる可きであるが，實際には低い場合が多いのは，經濟的發達に差がある 䳕であり，山地の有する交通の不便，或は，一方性，人口の稀薄，農耕地の 僅少且地力の瘦せたる等の條件が近代的產業發達の障害を成したのである。 詳しく觀察すれば西南日本では一般に山地は平地よりも指數が低く，殊に中 國山地，就中其の南本文び笠置山地，美濃越前加賀山地，能登牛島山地が低 い。唯紀伊山地及び室戸崎牛島の山地のみ指數が高い（20-50）。之に反し 東北日本殊に關東地方及び北海道では山地に於て寧ろ隣接する平野より指數 が高い。東北地方及び九州中部と南部にて山地と平地は明瞭存對照をなさぬ。 此等の關係は地域的であると同時に山地の地形に寺配されてねる。西南日本 外帶山地及び東北日本の山地の如く大起伏，大面積を有するものが，都市指 數高く，西南日本內帶と東北日本でも第三紀懕丘陵の如き小起伏山地に指數 が低い傾向が認められる。

38) 町村平均

北海道 $330 \mathrm{~km}^{2}$ 9900人 宮 崎 $81.5 \quad 7100$

鹿兒島

$65.3 \quad 9900$


平野と對照して山地の經濟は，農業上の技術的改良が困難で，且つ交通の 不便は商品經濟を妨げてるる。かくして經濟の發達が全然遲れた，人口不飽 和の山地は當然著しい低指數帶を成すべきである(例, 越後山地)。然し山地 の農業は人口飽容力少く, 技術的改良も困難就點ら，相對的人口飽和は寧 ろ本地より早く達せられる場合があらう。かかる場合，工業に人口の支持が 求められるが，工業資源たる山地の森林，動力，鑛物等は，其の山地の自然 的所與及び森林に就いては過去の伐探及び造林の狀熊が大いに影響する。概 して言へば，東北日本及び西苚日本外帶の山地に之等資源が豐かで，第三紀 層丘陵地及び西南日本內帶山地には乏しいと云つてよい。此の狀態が山地の 經濟變遷を二樣に導き，一は工業化されて大なる指數を持つ樣になり，他は 停洮を續けて，過剩人口を移住に依つて沙化したのであらう。秩父山地に於 ては，水田に乏しく烟地が卓越してねて，烟地の著しい桑園化は强商品經濟 化となり，更に製絲業織物業と一連の産業系統が發達したが，之には生綵輸 出港橫濱に近い事と動力の關係が與つてねると考へられる。要するに，我國 飞於て明治以後著しくなつた農業の發達, 工業化の刺载は平野にも山地にも 及んだが，事情に惠末れた山地では其の變化は却つて平野よりる先に進行し， 然らざる山地は取り殘されて未發澾の狀態を續け低い都市指數を保つてねる のである。

39）上田信三：秩父山地の耕作限界について地評 Vol. 13，pp. 227-242. 
地域別都市指數階級別分布表

\begin{tabular}{|c|c|c|c|c|c|c|c|c|c|c|c|}
\hline 指 數 階 級 & $C-5$ & \multicolumn{3}{|c|}{$5-10 \mid 10-15,15-20$} & $20-30$ & \multicolumn{2}{|c|}{$30-40 / 40-50$} & $50-70$ & \multicolumn{2}{|c|}{$|70-9090-100|$} & 計 \\
\hline 1)核心地域 & & & & & & & & & & & \\
\hline 畿 & & 4 & 55 & 79 & 170 & 159 & 130 & 204 & 100 & 55 & 956 \\
\hline$\%$ & & 0.4 & 5.8 & 8.3 & 17.8 & $16.6 \mid$ & 13.6 & 21.4 & 10.5 & 5.8 & 100 \\
\hline 2)亞核心地域 & & & & & & & & & & & \\
\hline 東 & & 1 & 17 & 46 & 55 & 52 & 38 & 51 & 39 & 58 & 357 \\
\hline 北 & & 8 & 26 & 24 & 45 & 34 & 24 & 26 & 9 & 14 & 210 \\
\hline 北 九 州 & & & 20 & 43 & 56 & 47 & 38 & 48 & 33 & 15 & 300 \\
\hline 計 & & 9 & 63 & 113 & 156 & 133 & 100 & 125 & 81 & 87 & 857 \\
\hline$\%$ & & 0.1 & 7.3 & 13.0 & 18.0 & 15.4 & 11.5 & 14.4 & 9.4 & 10.0 & 100 \\
\hline 3)漸移地域 I & & & & & & & & & & & \\
\hline 北 海 道 & & 10 & 33 & 46 & 76 & 46 & 25 & 20 & 9 & 6 & 271 \\
\hline 關巢西部 & 2 & 9 & 38 & 78 & 107 & 44 & 29 & 35 & 32 & 13 & 387 \\
\hline 東 山 & 4 & 61 & 102 & 94 & 121 & 66 & 40 & 52 & 30 & 12 & 582 \\
\hline 東海, 近畿宋部 & 2 & 41 & 179 & 166 & 253 & 168 & 91 & 109 & 49 & 17 & 1075 \\
\hline 近畿 北部 & & 11 & 49 & 60 & 81 & 31 & 18 & 27 & 13 & 7 & 297 \\
\hline 中 國 & 1 & 37 & 99 & 125 & 164 & 111 & 46 & 65 & 36 & 10 & 694 \\
\hline 四國, 淡路 & & 24 & 103 & 129 & 184 & 104 & 64 & 57 & 27 & 12 & 704 \\
\hline 九 & 1 & 7 & 36 & 55 & 82 & 39 & 19 & 30 & 10 & 6 & 285 \\
\hline 計 & 10 & 200 & 639 & 753 & 1068 & 609 & 332 & 395 & 206 & 83 & 4295 \\
\hline 4)漸移地域 II & 0.2 & 4.7 & 14.4 & 17.6 & 24.9 & 14.2 & 2.7 & 9.2 & 4.8 & 1.9 & 100 \\
\hline 東 & 6 & 81 & 183 & 137 & 132 & 62 & 25 & 38 & 22 & 13 & 699 \\
\hline 北 & 4 & 126 & 207 & 146 & 132 & 68 & 38 & 47 & 41 & 20 & 829 \\
\hline 中央山地 & & 50 & 111 & 98 & 80 & 33 & 18 & 19 & 15 & 3 & 427 \\
\hline 四國西部 & & 3 & 31 & 31 & 24 & 9 & 3 & 4 & 3 & 2 & 110 \\
\hline 州 & & 45 & 197 & 181 & 167 & 66 & 36 & 39 & 17 & 8 & 756 \\
\hline 計 & 10 & 305 & 729 & 593 & 535 & 238 & 120 & 147 & 98 & 46 & 2821 \\
\hline $\begin{array}{r}\% \\
\text { 5)緣邊地域 }\end{array}$ & 0.3 & 11.0 & 25.8 & 21.0 & 19.0 & 8.4 & 4.3 & 5.2 & 3.5 & 1.6 & 100 \\
\hline 東 & 13 & 184 & 209 & 118 & 106 & 49 & 30 & 41 & 25 & 5. & 780 \\
\hline 東 & & 113 & 362 & 216 & 174 & 78 & 51 & 54 & 38 & 12 & 1098 \\
\hline 山侩, 中國山地 & 3 & 105 & 224 & 184 & 158 & 67 & 37 & 35 & 18 & 6 & 837 \\
\hline
\end{tabular}




\begin{tabular}{|c|c|c|c|c|c|c|c|c|c|c|c|c|}
\hline 指 数 階 & 級 & $0-5$ & $5-10$ & $10-15$ & $15-20$ & $20-30$ & $30-40$ & $40-50$ & $50-70$ & $70-90$ & $90-100$ & 計 \\
\hline 九 & 州 & 12 & 29 & 45 & 38 & 48 & 14 & 8 & 3 & 2 & 2 & 201 \\
\hline 計 & & 28 & 431 & 840 & 556 & 486 & 208 & 126 & 133 & 83 & 25 & 1916 \\
\hline & & 1.0 & 14.8 & 23.9 & 19.1 & 16.7 & 7.1 & 4.3 & 4.6 & 2.3 & 0.9 & 100 \\
\hline 全國總 & & 49 & 948 & 2326 & 2097 & 2418 & 1344 & 806 & 1005 & 568 & 296 & 11855 \\
\hline 東 & 北 & 19 & 265 & 392 & 255 & 238 & 111 & 55 & 79 & 47 & 18 & 1479 \\
\hline 關 & 東 & 2 & 123 & 417 & 341 & 335 & 174 & 118 & 140 & 109 & 83 & 1842 \\
\hline 中 & 部 & 10 & 266 & 534 & 439 & 489 & 286 & 172 & 217 & 132 & 58 & 2603 \\
\hline 近 & 畿 & & 39 & 214 & 250 & 416 & 277 & 188 & 268 & 128 & 70 & 1850 \\
\hline 中 & 國 & 4 & 138 & 308 & 297 & 315 & 176 & 83 & 99 & 53 & 16 & 1489 \\
\hline 四 & 國 & & 27 & 130 & 150 & 196 & 108 & 64 & 62 & 28 & 14 & 779 \\
\hline 九 & 州 & 14 & 80 & 298 & 317 & 353 & 166 & 101 & 120 & 62 & 31 & 1542 \\
\hline 北 海 & 道 & & 10 & 33 & 46 & 76 & 45 & 25 & 20 & 9 & 6 & 271 \\
\hline
\end{tabular}


市町村别都市指數(郡每のメデアン)

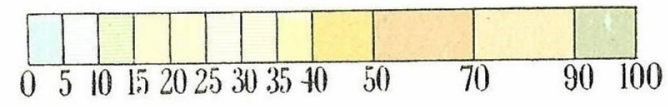

